\title{
Anti-EGFR Monoclonal Antibodies in Advanced Biliary Tract Cancer: A Systematic Review and Meta-analysis
}

\author{
ALESSANDRO RIZZO, GIORGIO FREGA, ANGELA DALIA RICCI, ANDREA PALLONI, FRANCESCA ABBATI, \\ STEFANIA DE LORENZO, MARZIA DESERTI, SIMONA TAVOLARI and GIOVANNI BRANDI \\ Department of Experimental, Diagnostic and Specialty Medicine, \\ S. Orsola-Malpighi University Hospital, Bologna, Italy
}

\begin{abstract}
Background: Despite several clinical trials and advances in understanding the genetic basis of biliary tract cancer (BTC), the addition of epidermal growth factor receptor (EGFR) targeted therapy does not seem to enhance the activity of first-line chemotherapy (CHT). Materials and Methods: We carried out a meta-analysis of available randomized clinical trials to assess the efficacy and safety of gemcitabine-based first-line CHT plus monoclonal antibodies against EGFR (EGFR-mAbs) in advanced or metastatic BTC. Results: In the overall population, the pooled hazard ratio for overall (OS) and progression-free (PFS) survival were $0.82 \quad(95 \%$ confidence interval $=0.64-1.06)$ and 0.88 (95\% confidence intervaI $=0.73-1.08)$, respectively. No differences were detected in objective response rate between the two groups. Patients treated with gemcitabine-based CHT plus EGFR-mAbs showed a statistically significant increased risk of grade 3-4 neutropenia, grade 3-4 thrombocytopenia and especially grade 3-4 skin rash. Conclusion: The addition of EGFR-mAbs to gemcitabine-based first-line CHT does not significantly improve overall and progression-free survival, nor the objective response rate in patients with advanced BTC and increases the risk of hematological and cutaneous adverse drug events.
\end{abstract}

Biliary tract cancer (BTC) is the second most common primary liver tumor accounting for approximately $10-15 \%$ of all hepatobiliary malignancies and $3 \%$ of all gastrointestinal

This article is freely accessible online.

Correspondence to: Rizzo Alessandro, Department of Experimental, Diagnostic and Specialty Medicine, S. Orsola-Malpighi University Hospital, Bologna, Italy. Tel: +39 0512144078, Fax: +39 0516364037,e-mail: rizzo.alessandro179@gmail.com

Key Words: Biliary tract cancer, BTC, anti-EGFR, cetuximab, panitumumab, KRAS, meta-analysis, review. neoplasms (1-3). BTCs include a heterogeneous group of malignancies usually divided into intrahepatic cholangiocarcinoma (iCCA), extrahepatic cholangiocarcinoma (eCCA), gallbladder cancer (GBC) and ampulla of Vater cancer (AVC), according to anatomical location $(4,5)$. Although traditionally considered rare tumors in Western countries, their incidence and mortality rate are on the whole rising worldwide. In particular, the incidence of iCCA is expected to further increase in the near future (6-9). Currently, radical surgery with microscopically negative resection margins is the only potentially curative therapy available, although most patients are diagnosed in late disease stages (locally advanced/ unresectable or metastatic) $(10,11)$. Moreover, even after complete surgical resection, the recurrence rate is high and the 5 -year overall survival (OS) rate remains discouraging (20$35 \%$ at 5 years) (12-14). Cisplatin plus gemcitabine is currently considered the standard first-line treatment for advanced or metastatic BTC, based on the results of the ABC-02 trial, where the OS was 11.7 months compared to 8.1 months in the gemcitabine single-agent arm [hazard ratio $(\mathrm{HR})=0.64,95 \%$ confidence intervaI $(\mathrm{CI})=0.52-0.80 ; \mathrm{p}<0.001]$ (15). The combination of gemcitabine and oxaliplatin is widely used in clinical practice in light of a similar antitumoral activity and a favorable safety profile compared to cisplatin - gemcitabine combination (16-18). Nevertheless, the prognosis of advanced or metastatic BTC is still poor, with an OS generally lower than 12 months $(19,20)$.

As a result of the increasing availability of genomic sequencing data, many signaling pathways and new genetic aberrations involved in the carcinogenesis of BTC have recently been delineated (21).

The mitogen-activated protein kinase (MAPK) pathway consists of a series of low-molecular-weight GTP-binding proteins related to the transduction of signals from cell surface receptors to the nuclear DNA (22). RAS represents the first step of this pathway and is involved in several biological processes including proliferation, growth, senescence and 
survival $(23,24)$. KRAS mutations and epidermal growth factor receptor (EGFR) overexpression are reported as common genetic alterations in BTC, whose frequency varies in the different anatomical subtypes (25-28). In a study by the Mayo Clinic group, KRAS mutations were detected in six out of 67 (9\%) cases of iCCA (29); in a Japanese study, these mutations were found in 10 out of 22 cases of iCCA (45\%), in 24 out of 36 cases of eCCA (67\%) and in 16 out of 19 GBC (84\%) (30). KRAS mutation has been associated with aggressive disease, reduced survival and perineural invasion in every anatomical subtype of BTC (31).

Several clinical trials have recently evaluated the role of EGFR-targeted drugs, usually divided into EGFR tyrosine kinase inhibitors (EGFR-TKIs) and monoclonal antibodies to EGFR (EGFR-mAbs), with disappointing results as monotherapy or in combination with chemotherapy (CHT) (32-37). Anti-EGFR agents are widely used in head and neck cancer, lung and colorectal cancer, given the benefits provided by these targeted therapies in the advanced or metastatic setting (38-41).

The aim of our meta-analysis was to evaluate the efficacy [in terms of OS, progression-free survival (PFS) and objective response rate (ORR)] and safety of gemcitabinebased CHT plus EGFR-mAbs in patients with advanced or metastatic BTC.

\section{Materials and Methods}

Search strategies. All phase II and III randomized clinical trials published until November 2, 2019 which compared gemcitabinebased first-line CHT plus EGFR-mAbs versus gemcitabine-based first-line CHT alone were selected (by A.R. and G.F.). Key words used for searching on PubMed/Medline, Cochrane library, and EMBASE were: "Gemcitabine", "EGFR-TKIs", "EGFR-mAbs", "EGFR", "Target Therapy", "Biliary Tract Cancer", "Cholangiocarcinoma", "Randomized Controlled Clinical Trial" and "Clinical Trial". Only articles published in peer-reviewed journals and written in the English language were considered. Furthermore, proceedings of the main international oncological meetings (American Society of Clinical Oncology, European Society of Medical Oncology, European Council of Clinical Oncology, American Association for Cancer Research, European Association of Gastroenterology, and Asian Pacific Association of Gastroenterology), were also searched from 2005 onward for relevant abstracts. Studies selected from the first analysis were then restricted to clinical trials and reviewed (by A.R. and G.F.). This meta-analysis was conducted according to Preferred Reporting Items for Systematic Review and Meta-Analyses (PRISMA) guidelines.

Types of outcome measures. Outcomes were divided into two groups: efficacy and toxicity. Efficacy outcomes included OS, PFS and ORR. OS was defined as the time from the date of random assignment to date of death as a result of any cause; PFS was defined as the time from random assignment in a clinical trial to disease progression or death from any cause. ORR included complete response and partial response. Toxicity data were classified according to World Health
Organization (WHO) or National Cancer Institute Common Toxicity Criteria (NCI-CTC) (42). We analyzed the most frequently reported grade 3-4 adverse events (ADEs).

Data extraction and synthesis. The following data were extracted for each publication: a: Study general information (author, year, phase, carry out country); b: primary site (iCCA, eCCA, GBC, AVC); c: interventions; d: dosage of drugs; e: number of patients; f: OS and PFS expressed as HRs for patients treated with combination therapy versus gemcitabine-based CHT alone; g: ORR; h: side-effects. Two separate Authors (A.R. and G.F.) conducted the search and identification independently.

Statistical design. Co-primary endpoints of the meta-analysis were OS and PFS for all patients. Meta-analyses were performed using Review Manager (Rev-Man 5.3) software, Version 5.3 (The Nordic Cochrane Centre, The Cochrane Collaboration, Copenhagen, Denmark). Time-to-event data (OS, PFS) were expressed as HRs of combination therapy over gemcitabine-based CHT alone, with $95 \%$ confidence intervals (CIs). The inverse variance technique was applied for the meta-analysis of the HR. Relative risks (RRs) were used to analyze dichotomous variables, including ORR and grade 34 adverse events; RRs were combined with Mantel-Haenszel method. Statistical heterogeneity between studies was examined using the chisquare test and the $\mathrm{I}^{2}$ statistic. Substantial heterogeneity was considered to exist when the $\mathrm{I}^{2}$ value was greater than $50 \%$ or there was a low $p$-value $(<0.10)$ from the chi-square test.

Assessment of risk of bias in included studies. Two authors (A.R and G.F.) independently assessed the risk of bias in included studies using the tools of The Cochrane Collaboration for assessing risk of bias (43): selection, performance, detection, attrition and reporting bias. Reporting bias was assessed by comparing the lists of outcomes from study protocols or trials registries to those reported in the published paper. The results were summarized in both a risk of bias graph (Figure 1) and a risk of bias summary (Figure 2). We interpreted the results of the meta-analyses in the light of the findings according to risk of bias.

\section{Results}

Studies selected. The search of electronic databases provided a total of 1,459 citations. An additional 45 records were identified from conference proceedings and trial registries, making a total of 1,504 search results. After adjusting for duplicates, excluding irrelevant topics, 24 records remained for examination in more detail. Eleven were excluded as there were no control arms and four were ongoing trials. Five randomized clinical trials (RCTs) were excluded because the experimental arm consisted of EGFR-TKIs. This left four RCTs to be included after independent evaluation of two Authors (A.R. and G.F.) (33-36). Figure 3 shows the search process.

A total of four RCTs comparing gemcitabine-based CHT plus EGFR-mAbs with gemcitabine-based CHT as first-line treatment were selected, including a total of 450 patients (228 in the combination arm, 222 in the gemcitabine-based CHT alone arm) (33-36). Both published full articles and study protocols were available in all four studies. One study 


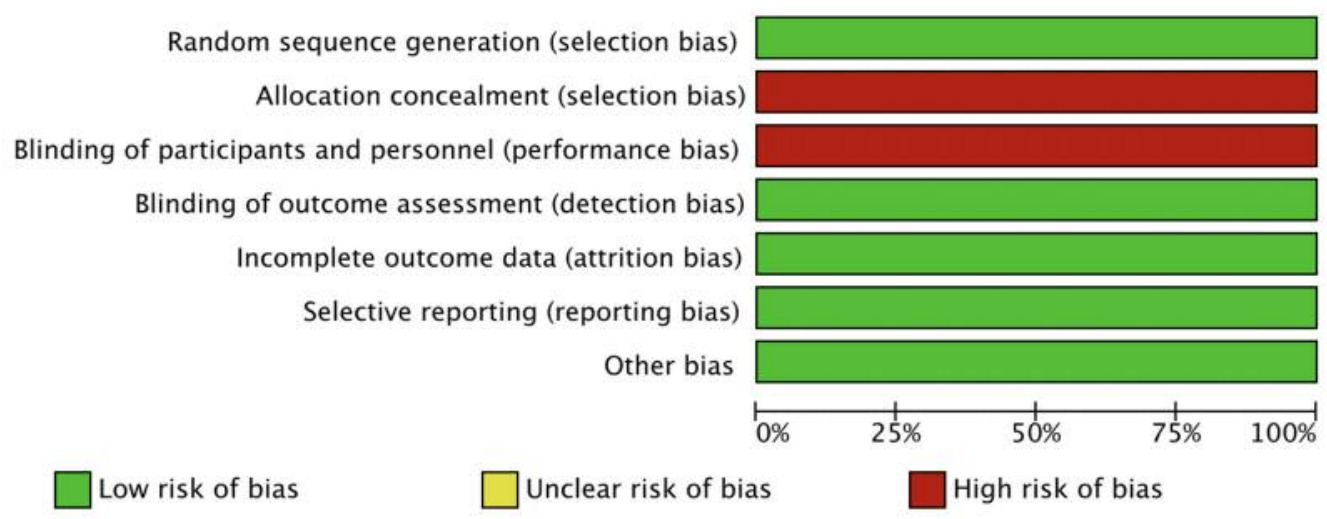

Figure 1. Risk of bias graph: Authors' judgements on each risk of bias item presented as percentages across all included studies.

was conducted in Italy (34), one in Taiwan (33), one in Germany (36) and one in France and Germany (35). All of the studies provided complete data for OS analysis, for PFS analysis and for grade 3-4 toxicities; three studies provided complete data for ORR. A summary of the included RCTs is presented in Table I.

$O S$. Four studies provided OS data on 450 patients affected by advanced BTC (33-36). The median OS ranged from 9.9 to 12.8 months in the combination of gemcitabine-based CHT with EGFR-mAbs and was 9.8-20.8 months for CHT alone. Addition of EGFR-mAbs did not show a significant OS benefit (pooled HR=0.82, 95\% CI=0.64-1.06) (Figure 4); the analysis was associated with a moderate level of heterogeneity ( $\mathrm{I}^{2}$ value of $\left.33 \%\right)$. Results did not differ whether fixed or randomized model effects were adopted.

PFS. The median PFS ranged from 5.3 to 6.7 months in the gemcitabine-based CHT plus anti-EGFR-mAbs arm and was 4.1-8.3 months for CHT alone; the addition of EGFR-mAbs to CHT did not result in a significant PFS benefit when compared to gemcitabine-based CHT alone (pooled $\mathrm{HR}=0.88,95 \% \mathrm{CI}=0.73-1.08$ ) (Figure 5).

ORR. Three studies provided objective response rate data on 361 patients affected by advanced BTC (33-35). No ORR superiority was reported by the addition of EGFR-mAbs, with a pooled RR of 1.34 (95\% CI=0.91-1.99) (Figure 6).

Toxicity. We assessed five types of frequently occurring grade 3-4 ADEs in terms of neutropenia, thrombocytopenia, skin rash, diarrhea and fatigue during the current analysis (Figures 7 to 11). Patients treated with gemcitabine-based first-line CHT and EGFR-targeted therapy had higher risk of neutropenia $(\mathrm{RR}=1.95,95 \% \quad \mathrm{CI}=1.13-3.36)$, thrombocytopenia $(\mathrm{RR}=1.69,95 \% \quad \mathrm{CI}=0.99-2.87)$ and

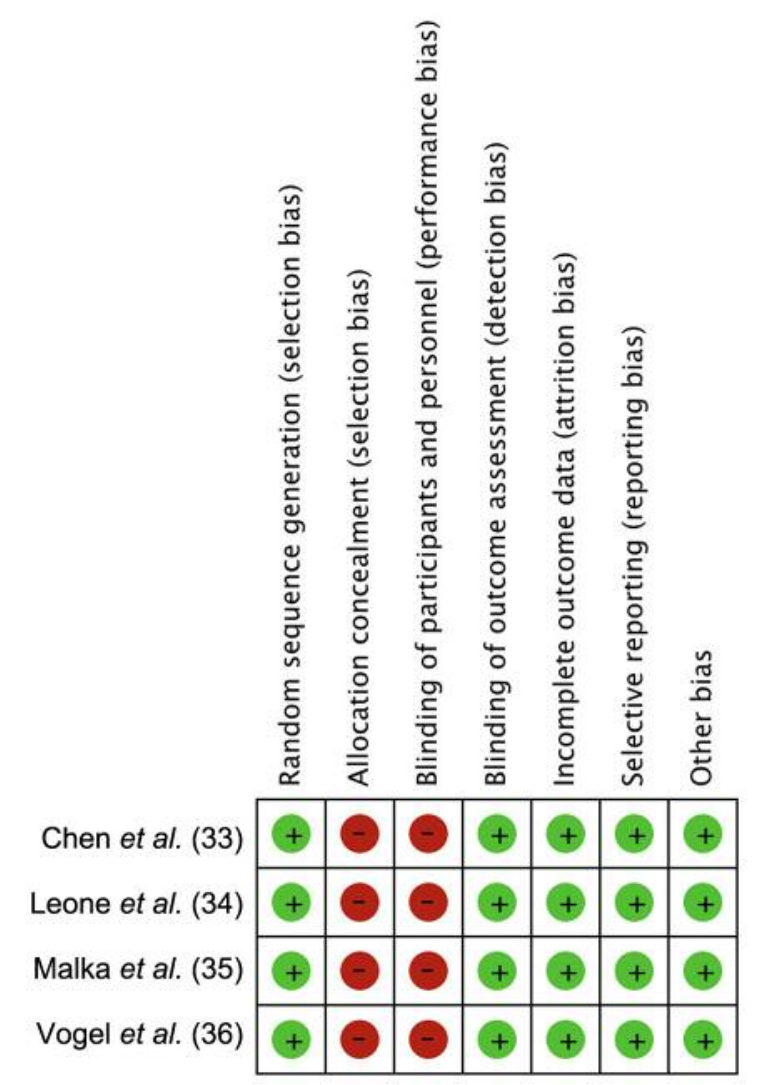

Figure 2. Risk of bias summary: Authors' judgments on each risk of bias item for each included study.

especially skin rash $(\mathrm{RR}=18.11,95 \% \mathrm{CI}=5.13-63.91)$. In addition, we compared the incidence of diarrhea $(\mathrm{RR}=2.01$, $95 \% \mathrm{CI}=0.91-4.44)$ and fatigue $(\mathrm{RR}=1.65,95 \% \mathrm{CI}=0.89$ 3.04) and no significant differences were observed between the two groups. 


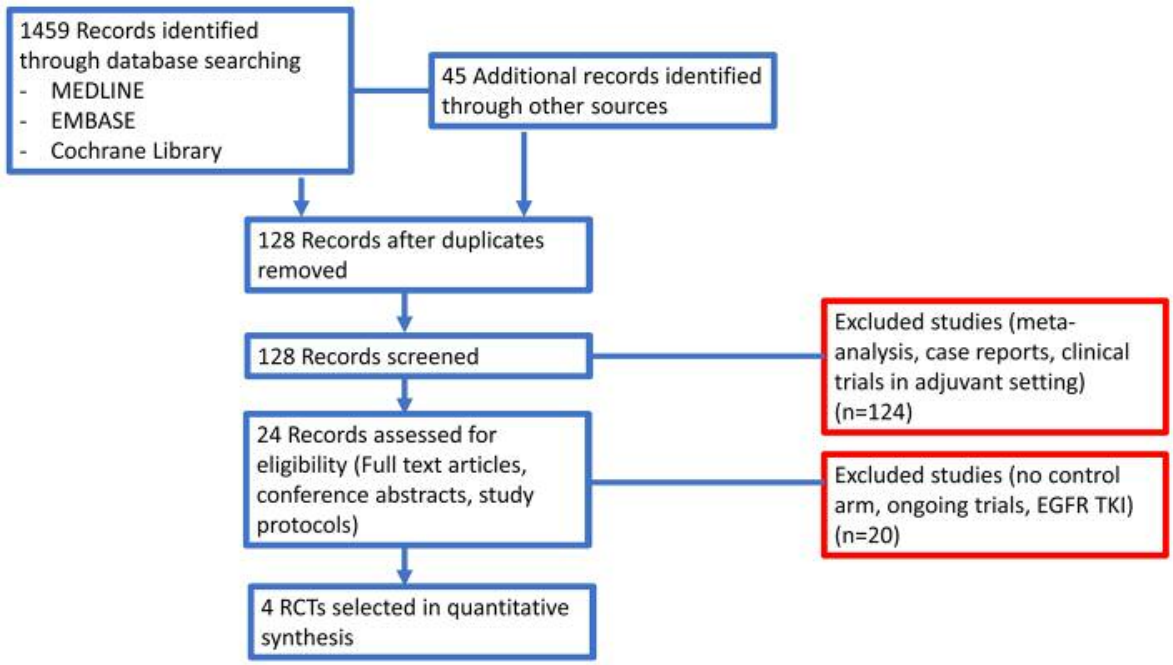

Figure 3. Study flow diagram.

Table I. Summary of the included studies. All were phase II clinical trials.

\begin{tabular}{|c|c|c|c|c|c|c|c|}
\hline $\begin{array}{l}\text { Author, year } \\
\text { (Ref) }\end{array}$ & $\begin{array}{c}\text { Primary } \\
\text { site }\end{array}$ & Country & $\begin{array}{l}\text { No. intervention/ } \\
\text { control }\end{array}$ & ECOG-PS & $\begin{array}{l}\text { Type of } \\
\text { treatment }\end{array}$ & Outcomes & $\begin{array}{c}\text { Full article } \\
\text { available }\end{array}$ \\
\hline $\begin{array}{l}\text { Malka et al. } \\
2014 \text { (35) }\end{array}$ & $\begin{array}{c}\text { iCCA, eCCA, } \\
\text { GBC, AVC }\end{array}$ & $\begin{array}{l}\text { France, } \\
\text { Germany }\end{array}$ & $76 / 74$ & $0,1,2$ & $\begin{array}{l}\text { Cetuximab }\left(500 \mathrm{mg} / \mathrm{m}^{2}\right) \text { plus } \\
\text { gemcitabine }\left(1000 \mathrm{mg} / \mathrm{m}^{2}\right) \text { and } \\
\text { oxaliplatin }\left(100 \mathrm{mg} / \mathrm{m}^{2}\right) \text { versus } \\
\text { gemcitabine }\left(1000 \mathrm{mg} / \mathrm{m}^{2}\right) \\
\text { and oxaliplatin }\left(100 \mathrm{mg} / \mathrm{m}^{2}\right)\end{array}$ & $\begin{array}{c}\text { OS } \\
\text { PFS } \\
\text { ORR } \\
\text { Toxicities }\end{array}$ & Yes \\
\hline $\begin{array}{l}\text { Chen et al., } \\
2015 \text { (33) }\end{array}$ & $\begin{array}{c}\text { iCCA, eCCA, } \\
\text { GBC }\end{array}$ & Taiwan & $62 / 60$ & 0,1 & $\begin{array}{l}\text { Cetuximab }\left(500 \mathrm{mg} / \mathrm{m}^{2}\right) \text { plus } \\
\text { gemcitabine }\left(800 \mathrm{mg} / \mathrm{m}^{2}\right) \text { and } \\
\text { oxaliplatin }\left(85 \mathrm{mg} / \mathrm{m}^{2}\right) \text { versus } \\
\text { gemcitabine }\left(800 \mathrm{mg} / \mathrm{m}^{2}\right) \text { and } \\
\text { oxaliplatin }\left(85 \mathrm{mg} / \mathrm{m}^{2}\right)\end{array}$ & $\begin{array}{c}\text { OS } \\
\text { PFS } \\
\text { ORR } \\
\text { Toxicities }\end{array}$ & Yes \\
\hline $\begin{array}{l}\text { Leone } \text { et al., } \\
2015 \text { (34) }\end{array}$ & $\begin{array}{c}\text { iCCA, eCCA, } \\
\text { GBC }\end{array}$ & Italy & $45 / 44$ & $0,1,2$ & $\begin{array}{c}\text { Panitumumab }(6 \mathrm{mg} / \mathrm{kg}) \text { plus } \\
\text { gemcitabine }\left(1000 \mathrm{mg} / \mathrm{m}^{2}\right) \text { and } \\
\text { oxaliplatin }\left(100 \mathrm{mg} / \mathrm{m}^{2}\right) \text { versus } \\
\text { gemcitabine }\left(1000 \mathrm{mg} / \mathrm{m}^{2}\right) \text { and } \\
\text { oxaliplatin }\left(100 \mathrm{mg} / \mathrm{m}^{2}\right)\end{array}$ & $\begin{array}{c}\text { OS } \\
\text { PFS } \\
\text { ORR } \\
\text { Toxicities }\end{array}$ & Yes \\
\hline $\begin{array}{l}\text { Vogel et al., } \\
2018 \text { (36) }\end{array}$ & $\begin{array}{c}\text { iCCA, eCCA, } \\
\text { GBC }\end{array}$ & Germany & $62 / 28$ & $0,1,2$ & $\begin{array}{l}\text { Panitumumab }(9 \mathrm{mg} / \mathrm{kg}) \text { plus } \\
\text { gemcitabine }\left(1000 \mathrm{mg} / \mathrm{m}^{2}\right) \text { and } \\
\text { cisplatin }\left(25 \mathrm{mg} / \mathrm{m}^{2}\right) \text { versus } \\
\text { gemcitabine }\left(1000 \mathrm{mg} / \mathrm{m}^{2}\right) \text { and } \\
\text { cisplatin }\left(25 \mathrm{mg} / \mathrm{m}^{2}\right)\end{array}$ & $\begin{array}{c}\text { OS } \\
\text { PFS } \\
\text { Toxicities }\end{array}$ & Yes \\
\hline
\end{tabular}

CT: Clinical trial; iCCA: intrahepatic cholangiocarcinoma; eCCA: extrahepatic cholangiocarcinoma; GBC: gallbladder cancer; AVC: carcinoma of the ampulla of Vater; ECOG-PS: Eastern Cooperative Oncology Group, performance status; OS: overall survival; PFS: progression-free survival; ORR: objective response rate.

\section{Discussion}

BTCs are a heterogeneous group of aggressive malignancies comprising iCCA, eCCA, GBC and AVC, according to anatomical location. Although each subtype presents distinct biology, risk factors, molecular pathogenesis, prognosis, therapeutic options and epidemiology, RCTs often include patients affected by all these anatomical subtypes, which is a problematic issue in interpreting results.

The advent and the development of comprehensive wholeexome and transcriptome sequencing has led to a growing pharmaceutical and scientific interest in developing targeted 


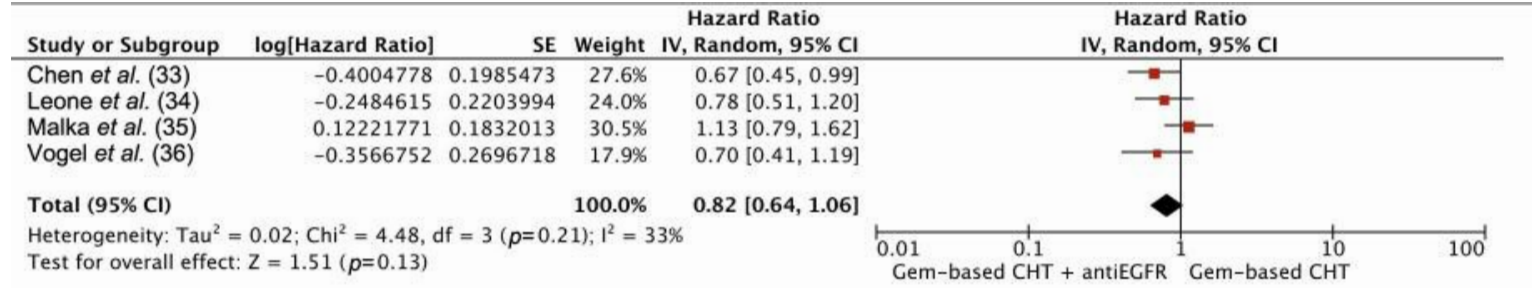

Figure 4. Forest plot of comparison between gemcitabine (Gem)-based chemotherapy (CHT) plus anti-epidermal growth factor receptor (EGFR) versus gemcitabine-based chemotherapy alone; the outcome was hazard ratio of overall survival. CI: Confidence intervaI.

$\begin{array}{lrrrrr}\text { Study or Subgroup } & \text { log[Hazard Ratio] } & \text { SE } & \text { Weight } & \begin{array}{c}\text { Hazard Ratio } \\ \text { IV, Fixed, 95\% Cl }\end{array} & \text { Hazard Ratio } \\ \text { IV, Fixed, 95\% CI }\end{array}$

Figure 5. Forest plot of comparison between gemcitabine (Gem)-based chemotherapy (CHT) plus anti-epidermal growth factor receptor (EGFR) versus gemcitabine-based chemotherapy alone; the outcome was hazard ratio of progression-free survival. CI: Confidence intervaI.

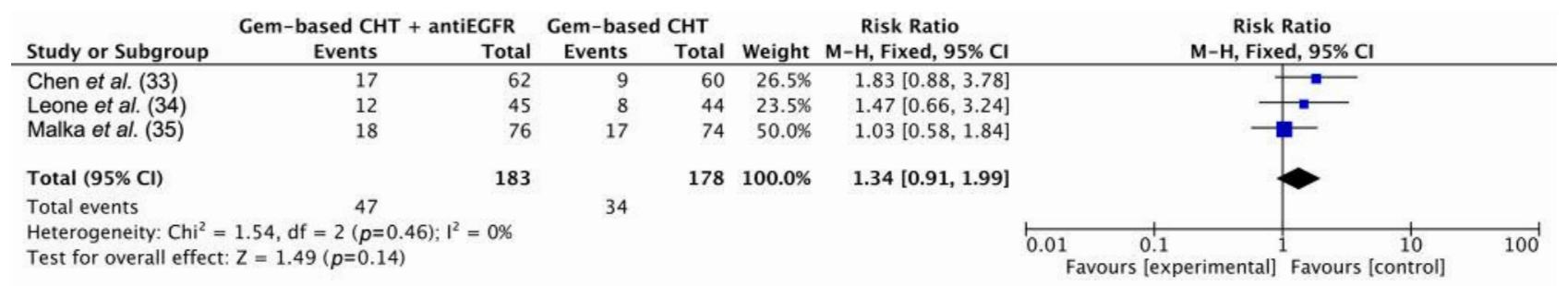

Figure 6. Forest plot of comparison between gemcitabine (Gem)-based chemotherapy (CHT) plus anti-epidermal growth factor receptor (EGFR) versus gemcitabine-based chemotherapy alone; the outcome was risk ratio of objective response rate. CI: Confidence interval.

agents in BTC. In this landscape, promising molecular targets for precision medicine in advanced BTC have been evaluated and are currently under investigation, representing a new option for a proportion of selected candidates (21). Between the novel treatments explored in RCTs, in recent years several EGFR-targeted therapies (single-agent or in addition to CHT) have been tested in various trials, failing to produce promising results (33-37).

Our meta-analysis especially focused on the efficacy and safety of gemcitabine-based CHT plus EGFR-mAbs. The results of our meta-analysis confirmed no beneficial OS, PFS and ORR was observed in the pooled analysis with the addition of EGFR-targeted therapy to first-line CHT. As regards PFS, the absence of heterogeneity in the overall analysis for PFS suggested that the lack of efficacy was not dependent on the regimen used. Our results were in line with similar meta-analyses performed by Cai et al. (44) and Zhuang et al. (45), in which the authors detected a remarkable superiority of ORR, although this finding did not translate into a PFS and OS benefit. However, in contrast to their analyses, we included only the results of RCTs on gemcitabine-based CHT plus EGFR-mAbs excluding EGFRTKIs. Of note, Cai et al. and Zhuang et al. did not find significant differences comparing grade 3-4 adverse events in either group.

In our analysis, we pooled five types of grade 3-4 ADEs. While no significant differences were found in the incidence of diarrhea and fatigue, the pooled data illustrated that more 
in vivo $34: 479-488(2020)$

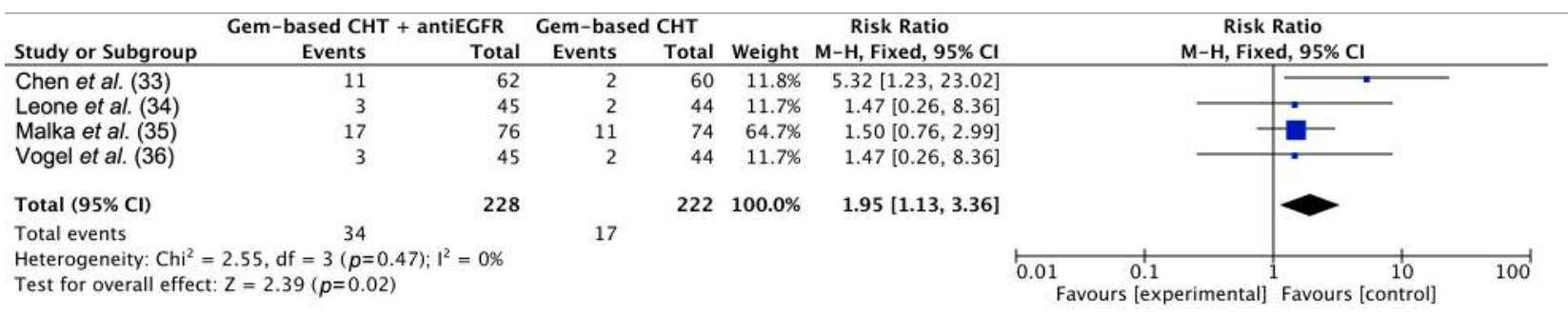

Figure 7. Forest plot of comparison between gemcitabine (Gem)-based chemotherapy (CHT) plus anti-epidermal growth factor receptor (EGFR) versus gemcitabine-based chemotherapy alone; the outcome was risk ratio of neutropenia. CI: Confidence interval.

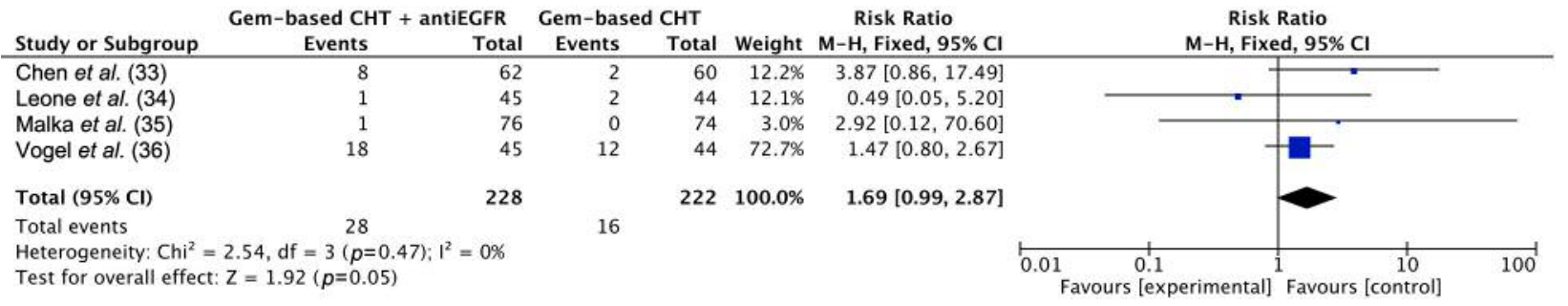

Figure 8. Forest plot of comparison between gemcitabine (Gem)-based chemotherapy (CHT) plus anti-epidermal growth factor receptor (EGFR) antibodies versus gemcitabine-based chemotherapy alone; the outcome was risk ratio of thrombocytopenia. CI: Confidence interval.

\begin{tabular}{|c|c|c|c|c|c|c|c|c|c|c|}
\hline \multirow[b]{2}{*}{ Study or Subgroup } & \multicolumn{2}{|c|}{ Gem-based CHT + antiEGFR } & \multicolumn{2}{|c|}{ Gem-based CHT } & \multirow[b]{2}{*}{ Weight } & \multirow{2}{*}{$\begin{array}{c}\text { Risk Ratio } \\
\text { M-H, Fixed, } 95 \% \mathrm{Cl}\end{array}$} & \multirow{2}{*}{\multicolumn{4}{|c|}{$\begin{array}{c}\text { Risk Ratio } \\
\text { M-H, Fixed, 95\% CI }\end{array}$}} \\
\hline & Events & Total & Events & Total & & & & & & \\
\hline Chen et al. (33) & 27 & 62 & 0 & 60 & $20.1 \%$ & $53.25[3.32,853.82]$ & & & & 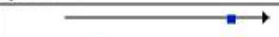 \\
\hline Leone et al. (34) & 6 & 45 & 1 & 44 & $39.9 \%$ & $5.87[0.74,46.76]$ & & & & $=$ \\
\hline Malka et al. (35) & 5 & 76 & 0 & 74 & $20.0 \%$ & $10.71[0.60,190.40]$ & & & & \\
\hline Vogel et al. (36) & 7 & 45 & 0 & 44 & $20.0 \%$ & $14.67[0.86,249.42]$ & & & & \\
\hline Total $(95 \% \mathrm{Cl})$ & & 228 & & 222 & $100.0 \%$ & $18.11[5.13,63.91]$ & & & & \\
\hline Total events & 45 & & 1 & & & & & & & \\
\hline $\begin{array}{l}\text { Heterogeneity: } \mathrm{Chi}^{2}= \\
\text { Test for overall effec }\end{array}$ & $\begin{array}{l}1.86, \mathrm{df}=3(p= \\
Z=4.50(p<0.0\end{array}$ & $0 \%$ & & & & & 0.01 & $\begin{array}{l}0.1 \\
s[\mathrm{exp}\end{array}$ & erimental] $\mathrm{F}$ & $\begin{array}{c}10 \\
\text { Favours [control] }\end{array}$ \\
\hline
\end{tabular}

Figure 9. Forest plot of comparison between gemcitabine (Gem)-based chemotherapy (CHT) plus anti-epidermal growth factor receptor (EGFR) antibodies versus gemcitabine-based chemotherapy alone; the outcome was risk ratio of skin rash. CI: Confidence interval.

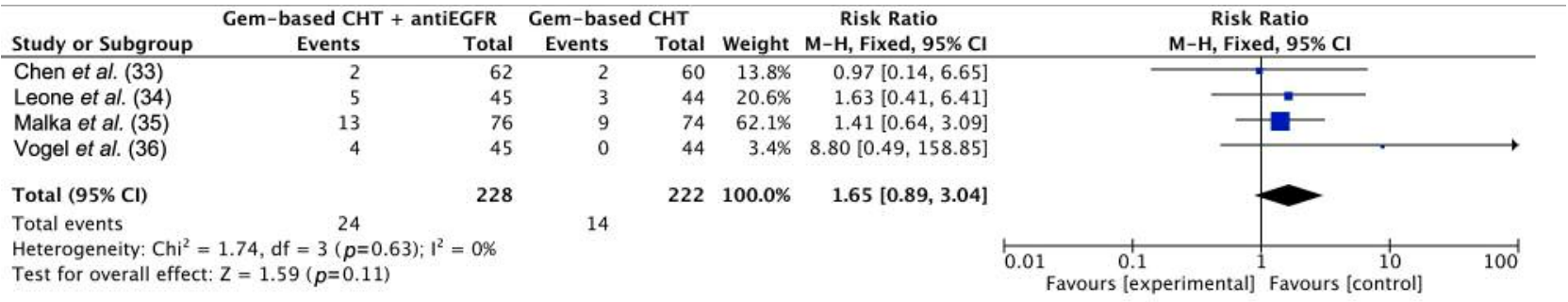

Figure 10. Forest plot of comparison between gemcitabine (Gem)-based chemotherapy (CHT) plus anti-epidermal growth factor receptor (EGFR) antibodies versus gemcitabine-based chemotherapy alone; the outcome was risk ratio of diarrhea. CI: Confidence interval. 


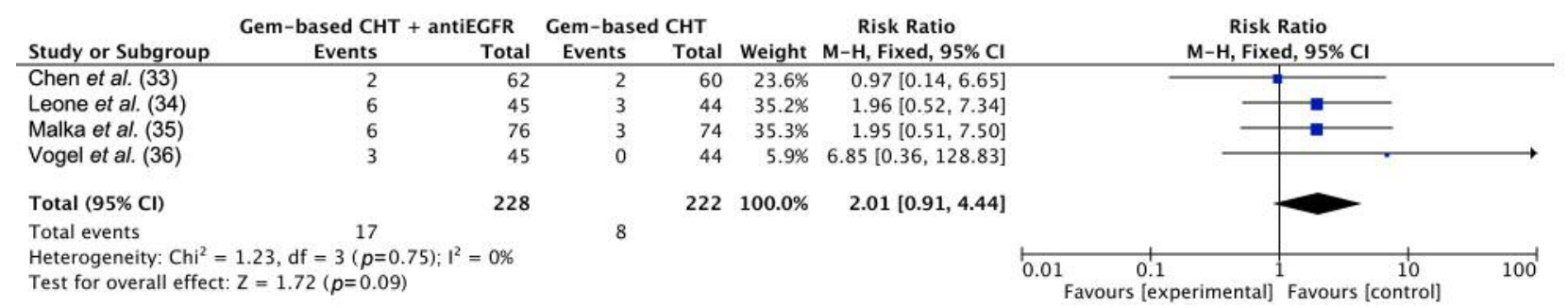

Figure 11. Forest plot of comparison between gemcitabine (Gem)-based chemotherapy (CHT) plus anti-epidermal growth factor receptor (EGFR) antibodies versus gemcitabine-based chemotherapy alone; the outcome was risk ratio of fatigue. CI: Confidence interval.

statistically significant hematological toxicities occurred in the CHT plus targeted therapy arm than in the one treated with CHT alone.

The same results were found in the incidence of skin rash, a frequently observed grade 3-4 ADE in the group treated with gemcitabine-based CHT plus EGFR-mAbs. In lung cancer, skin rash occurrence is considered a strong predictor of outcome in patients treated with EGFR-targeted therapy on the basis of its association with reduced risk of death and increased chance of response $(46,47)$. A recent meta-analysis analyzed data from 14 RCTs on anti-EGFR treatment and skin rash in biliary tract cancer (48); in this study, a longer OS $(\mathrm{HR}=0.47,95 \% \mathrm{CI}=0.31-0.71, p=0.0003)$ and PFS $(\mathrm{HR}=0.51$, $95 \% \mathrm{CI}=0.36-0.72, p=0.0001)$ was described in patients with higher grades of skin rash when compared with patients who received the same treatment but had lower grades or no skin rash. To date, the predictive role of skin rash for BTC patients receiving EGFR-targeted agents is not defined.

There are several limitations which might have influenced the results of this meta-analysis.

Firstly, only four RCTs were included, with small sample sizes, and all the included studies were industry funded. Secondly, two types of gemcitabine-based schedules and two different types of EGFR-mAbs (cetuximab and panitumumab) were included. Additionally, the metaanalyses included two RCTs $(33,35)$ with molecularly unselected patients, regardless of $K R A S$ status, which would have a non-negligible effect on results.

Moreover, given the well-known biological heterogeneity of anatomical subtypes included in BTC, the inclusion of tumors arising from the biliary tree together with GBC and AVC might meaningfully influence the possibility of recognizing a survival benefit. This long-standing issue in the interpretation and generalizability of RCTs on BTC may be surmounted only through a more accurate selection of patients in future prospective trials.

In the current era of precision oncology, a mandatory point would be to better define genes and pathways involved in BTC to provide a deeper understanding of biological mechanisms underlying iCCA, eCCA, GBC and AVC. Progress in the management of BTC will necessarily have to pass through a close collaboration between molecular biology and clinical oncology in order to modify the natural history of this increasingly frequent, highly lethal, disease.

\section{Conclusion}

On the basis of this meta-analysis, the addition of EGFR-mAbs to gemcitabine-based first-line CHT in advanced BTC does not result in a statistically significant benefit in OS, PFS and ORR with increased grade 3-4 toxicity, and thus these agents should not be adopted into clinical practice. Further exploration of tumor biology and genetic aberrations in BTC is needed to improve patient outcomes that remain unsatisfactory.

\section{Conflicts of Interest}

The Authors state that they have no conflicts of interest in regard to this study.

\section{Authors' Contributions}

Rizzo A: Made substantial contributions to conception of the study, analyzed the data and drafted the article; Frega G: made substantial contributions to conception of the study and gave final approval of the version to be published; Ricci AD: made substantial contributions to conception of the study, analyzed the data and was involved in revising the article critically for important intellectual content; Palloni A: helped to draft and revise the article; Abbati F: helped to draft and revise the article; De Lorenzo S: revised the article; Deserti M: revised the article; Tavolari S: made substantial contributions to conception of the study and revised the article; Brandi G: was involved in revising the article critically for important intellectual content and gave final approval of the version to be published. All Authors critically revised the article, approved the final version to be published, and agree to be accountable for all aspects of the work.

\section{Acknowledgements}

The Authors received no financial support for the research, authorship, or publication of this article. 


\section{References}

1 Khan SA, Tavolari S and Brandi G: Cholangiocarcinoma: Epidemiology and risk factors. Liver Int 39(Suppl 1): 19-31, 2019. PMID: 30851228. DOI: 10.1111/liv.14095

2 Fitzmaurice C, Dicker D, Pain A, Hamavid H, Moradi-Lakeh M, MacIntyre MF, Allen C, Hansen G, Woodbrook R, Wolfe C, Hamadeh RR, Moore A, Werdecker A, Gessner BD, Te Ao B, McMahon B, Karimkhani C, Yu C, Cooke GS, Schwebel DC, Carpenter DO, Pereira DM, Nash D, Kazi DS, De Leo D, Plass D, Ukwaja KN, Thurston GD, Yun Jin K, Simard EP, Mills E, Park EK, Catalá-López F, deVeber G, Gotay C, Khan G, Hosgood HD 3rd, Santos IS, Leasher JL, Singh J, Leigh J, Jonas JB, Sanabria J, Beardsley J, Jacobsen KH, Takahashi K, Franklin RC, Ronfani L, Montico M, Naldi L, Tonelli M, Geleijnse J, Petzold M, Shrime MG, Younis M, Yonemoto N, Breitborde N, Yip P, Pourmalek F, Lotufo PA, Esteghamati A, Hankey GJ, Ali R, Lunevicius R, Malekzadeh R, Dellavalle R, Weintraub R, Lucas R, Hay R, Rojas-Rueda D, Westerman R, Sepanlou SG, Nolte S, Patten S, Weichenthal S, Abera SF, Fereshtehnejad SM, Shiue I, Driscoll T, Vasankari T, Alsharif U, Rahimi-Movaghar V, Vlassov VV, Marcenes WS, Mekonnen W, Melaku YA, Yano Y, Artaman A, Campos I, MacLachlan J, Mueller U, Kim D, Trillini M, Eshrati B, Williams HC, Shibuya K, Dandona R, Murthy K, Cowie B, Amare AT, Antonio CA, Castañeda-Orjuela C, van Gool CH, Violante F, Oh IH, Deribe K, Soreide K, Knibbs L, Kereselidze M, Green M, Cardenas R, Roy N, Tillmann T, Li Y, Krueger H, Monasta L, Dey S, Sheikhbahaei S, Hafezi-Nejad N, Kumar GA, Sreeramareddy CT, Dandona L, Wang H, Vollset SE, Mokdad A, Salomon JA, Lozano R, Vos T, Forouzanfar M, Lopez A, Murray C and Naghavi M: The global burden of cancer 2013. JAMA Oncol 1(4): 505-527, 2015. PMID: 26181261. DOI: 10.1001/jamaoncol.2015.0735

3 Razumilava N and Gores GJ: Cholangiocarcinoma. Lancet 383(9935): 2168-2179, 2014. PMID: 24581682. DOI: 10.1016/ S0140-6736(13)61903-0

4 Valle J, Borbath I, Khan SA, Huguet F and Gruenberger T, Arnold D; ESMO Guidelines Committee. Biliary cancer: ESMO Clinical Practice Guidelines for diagnosis, treatment and followup. Ann Oncol 27(Suppl 5): v28-v37, 2016. PMID: 27664259. DOI: $10.1093 /$ annonc/mdw324

5 Cardinale V, Bragazzi MC, Carpino G, Torrice A, Fraveto A, Gentile R, Pasqualino V, Melandro F, Aliberti C, Bastianelli C, Brunelli R, Berloco PB, Gaudio E and Alvaro D: Cholangiocarcinoma: increasing burden of classifications. Hepatobiliary Surg Nutr 2: 272-280, 2013. PMID: 24570958. DOI: $10.3978 /$ j.issn.2304-3881.2013.10.02

6 Saha SK, Zhu AX, Fuchs CS and Brooks GA: Forty-year trends in cholangiocarcinoma incidence in the US: intrahepatic disease on the rise. Oncologist 21: 594-599, 2016. PMID: 27000463. DOI: 10.1634 /theoncologist.2015-0446

7 Khan SA, Taylor-Robinson SD, Toledano MB, Beck A, Elliott P and Thomas HC: Changing international trends in mortality rates for liver, biliary and pancreatic tumours. J Hepatol 37: 806-813, 2002. PMID: 12445422. DOI: 10.1016/s0168-8278(02)00297-0

8 Banales JM, Cardinale V, Carpino G, Marzioni M, Andersen JB, Invernizzi $\mathrm{P}$, Lind GE, Folseraas T, Forbes SJ, Fouassier L, Geier A, Calvisi DF, Mertens JC, Trauner M, Benedetti A, Maroni L, Vaquero J, Macias RI, Raggi C, Perugorria MJ, Gaudio E, Boberg KM, Marin JJ and Alvaro D: Expert consensus document: Cholangiocarcinoma: current knowledge and future perspectives consensus statement from the European Network for the Study of Cholangiocarcinoma (ENS-CCA). Nat Rev Gastroenterol Hepatol 13(5): 261-280, 2016. PMID: 27095655. DOI: $10.1038 /$ nrgastro.2016.51

9 Smittenaar CR, Petersen KA, Stewart K and Moitt N: Cancer incidence and mortality projections in the UK until 2035. Br J Cancer 115(9): 1147-1155, 2016. PMID: 27727232. DOI: 10.1038/bjc.2016.304

10 DeOliveira ML, Cunningham SC, Cameron JL, Kamangar F, Winter JM, Lillemoe KD, Choti MA, Yeo CJ and Schulick RD: Cholangiocarcinoma: thirty-one-year experience with 564 patients at a single institution. Ann Surg 245: 755-762, 2007. PMID: 17457168. DOI: 10.1097/01.sla.0000251366.62632.d3

11 Schweitzer N, Fischer M, Kirstein MM, Berhane S, Kottas M, Sinn M, Gonzalez-Carmona MA, Balta Z, Weismüller TJ, Strassburg CP, Reineke-Plaaß T, Bektas H, Manns MP, Johnson P, Weinmann A and Vogel A: Risk estimation for biliary tract cancer: Development and validation of a prognostic score. Liver Int 37(12): 1852-1860, 2017. PMID: 28695669. DOI: 10.1111/liv.13517

12 Inoue K, Makuuchi M, Takayama T, Torzilli G, Yamamoto J, Shimada K, Kosuge T, Yamasaki S, Konishi M, Kinoshita T, Miyagawa $\mathrm{S}$ and Kawasaki S: Long-term survival and prognostic factors in the surgical treatment of mass-forming type cholangiocarcinoma. Surgery 127: 498-505, 2000. PMID: 10819057. DOI: $10.1067 /$ msy.2000.104673

13 Cho SY, Park SJ, Kim SH, Han SSM Kim YK, Lee KW, Lee SA, Hong EK, Lee WJ and Woo SM: Survival analysis of intrahepatic cholangiocarcinoma after resection. Ann Surg Oncol 17: 1823-1830, 2010. PMID: 20165987. DOI: 10.1245/s10434010-0938-y

14 Jan YY, Yeh CN, Yeh TS, Hwang TL and Chen MF: Clinicopathological factors predicting long-term overall survival after hepatectomy for peripheral cholangiocarcinoma. World J Surg 29: 894-898, 2005. PMID: 1595131. DOI: 10.1007/s00268005-7763-7

15 Valle J, Wasan H, Palmer DH, Cunningham D, Anthoney A, Maraveyas A, Madhusudan S, Iveson T, Hughes S, Pereira SP, Roughton M, Bridgewater J and ABC-02 Trial Investigators: Cisplatin plus gemcitabine versus gemcitabine for biliary tract cancer. N Engl J Med 362: 1273-1281, 2010. PMID: 20375404. DOI: $10.1056 /$ NEJMoa0908721

16 Andre T, Tournigand C, Rosmorduc O, Provent S, MaindraultGoebel F, Avenin D, Selle F, Paye F, Hannoun L, Houry S, Gayet B, Lotz JP, de Gramont A, Louvet C and GERCOR Group: Gemcitabine combined with oxaliplatin (GEMOX) in advanced biliary tract adenocarcinoma: a GERCOR study. Ann Oncol 15: 1339-1343, 2004. PMID: 15319238. DOI: 10.1093/ annonc/mdh351

17 Harder J, Riecken B, Kummer O, Lohrmann C, Otto F, Usadel $\mathrm{H}$, Geissler M, Opitz O and Henss H: Outpatient chemotherapy with gemcitabine and oxaliplatin in patients with biliary tract cancer. Br J Cancer 95: 848-852, 2006. PMID: 16969352. DOI: 10.1038/sj.bjc.6603334

18 Jang JS, Lim HY, Hwang IG, Song HS, Yoo N, Yoon S, Kim YH, Park E, Byun JH, Lee MA, Oh SJ, Lee KH, Kim SC, Oh SC, Kim SY and Lee SJ: Gemcitabine and oxaliplatin in patients with unresectable biliary cancer including gall bladder cancer: a Korean Cancer Study Group phase II trial. Cancer Chemother 
Pharmacol 65: 641-647, 2010. PMID: 19652971. DOI: 10.1007/s00280-009-1069-7

19 Sharma A, Dwary AD, Mohanti BK, Deo SV, Pal S, Sreenivas V, Raina V, Shukla NK, Thulkar S, Garg P and Chaudhary SP: Best supportive care compared with chemotherapy for unresectable gallbladder cancer: a randomized controlled study. J Clin Oncol 28: 4581-4586, 2010. PMID: 20855823. DOI: 10.1200/JCO.2010.29.3605

20 Eckel F and Schmid RM: Chemotherapy in advanced biliary tract carcinoma: a pooled analysis of clinical trials. Br J Cancer 96: 896-902, 2007. PMID: 17325704. DOI: 10.1038/sj.bjc.6603648

21 Adeva J, Sangro B, Salati M, Edeline J, La Casta A, Bittoni A, Berardi R, Bruix $\mathrm{J}$ and Valle JW: Medical treatment for cholangiocarcinoma. Liver Int 39(Suppl 1): 123-142, 2019. PMID: 30892822. DOI: 10.1111/liv.14100

22 Brandi G, Farioli A, Astolfi A, Biasco G and Tavolari S: Genetic heterogeneity in cholangiocarcinoma: a major challenge for targeted therapies. Oncotarget 6(17): 14744-14753, 2015. PMID: 26142706. DOI: 10.18632/oncotarget.4539

23 Rajalingam K, Schreck R, Rapp UR and Albert S: Ras oncogenes and their downstream targets. Biochim Biophys Acta 1773: 1177-1195, 2007. PMID: 17428555. DOI: 10.1016/ j.bbamcr.2007.01.012

24 Robertson S, Hyder O, Dodson R, Nayar SK, Poling J, Beierl K, Eshleman JR, Lin MT, Pawlik TM and Anders RA: The frequency of KRAS and BRAF mutations in intrahepatic cholangiocarcinomas and their correlation with clinical outcome. Hum Pathol 44(12): 2768-2773, 2013. PMID: 24139215. DOI: 10.1016/j.humpath.2013.07.026

25 Kipp BR, Fritcher EG, Clayton AC, Gores GJ, Roberts LR, Zhang J, Levy MJ and Halling KC: Comparison of KRAS mutation analysis and FISH for detecting pancreatobiliary tract cancer in cytology specimens collected during endoscopic retrograde cholangiopancreatography. J Mol Diagn 12(6): 780786, 2010. PMID: 20864634. DOI: 10.253/jmoldx.2010.100016

26 O’Dell MR, Huang JL, Whitney-Miller CL, Deshpande V, Rothberg P, Grose V, Rossi RM, Zhu AX, Land H, Bareesy N and Hezel AF: Kras(G12D) and p53 mutation cause primary intrahepatic cholangiocarcinoma. Cancer Res 72(6): 1557-1567, 2012. PMID: 22266220. DOI: 10.1158/0008-542.CAN-11-3596

27 Ong CK, Subimerb C, Pairojkul C, Wongkham S, Cutcutache I, Yu W, McPherson JR, Allen GE, Ng CC, Wong BH, Myint SS, Rajasegaran V, Heng HL, Gan A, Zang ZJ, Wu Y, Wu J, Lee MH, Huang D, Ong P, Chan-on W, Cao Y, Qian CN, Lim KH, Ooi A, Dykema K, Furge K, Kukongviriyapan V, Sripa B, Wongkham C, Yongvanit P, Futreal PA, Bhudhisawasdi V, Rozen $\mathrm{S}$, Tan $\mathrm{P}$ and Teh BT: Exome sequencing of liver flukeassociated cholangiocarcinoma. Nat Genet 44(6): 690-693, 2012. PMID: 22561520. DOI: $10.1038 / \mathrm{ng} .2273$

28 Nakazawa K, Dobashi Y, Suzuki S, Fujii H, Takeda Y and Ooi A: Amplification and overexpression of c-erbB-2, epidermal growth factor receptor, and c-met in biliary tract cancers. J Pathol 206(3): 356-365, 2005. PMID: 15892172. DOI: 10.1002/path.1779

29 Voss JS, Holtegaard LM, Kerr SE, Fritcher EG, Roberts LR, Gores GJ, Zhang J, Highsmith WE, Halling KC and Kipp BR: Molecular profiling of cholangiocarcinoma shows potential for targeted therapy treatment decisions. Hum Pathol 44(7): 1216-1222, 2013. PMID: 23391413. DOI: 10.1016/j.humpath.2012.11.006

30 Ohashi K, Tstsumi M, Nakajima Y, Nakano H and Konishi Y: $\mathrm{Ki}$-ras point mutations and proliferation activity in biliary tract carcinomas. Br J Cancer 74(6): 930-935, 1996. PMID: 8826860. DOI: $10.1038 /$ bjc. 1996.459

31 Chen TC, Jan YY and Yeh TS: K-ras mutation is strongly associated with perineural invasion and represents an independent prognostic factor of intrahepatic cholangiocarcinoma after hepatectomy. Ann Surg Oncol 19(S3): 675-681, 2012. PMID: 22805857. DOI: $10.1245 / \mathrm{s} 10434-012-2224-7$

32 Sohal DPS, Mykulowycz K, Uehara T, Teitelbaum UR, Damjanov N, Gianantonio BJ, Carberry M, Wissel P, JcobsSmall M, O'Dwyer PJ, Sepulveda A and Sun W: A phase II trial of gemcitabine, irinotecan and panitumumab in advanced cholangiocarcinoma. Ann Oncol 24(12): 3061-3065, 2013. PMID: 24146220. DOI: 10.1093/annonc/mdt416

33 Chen J, Hsu CCN, Chiang NJ, Tsai CS, Tsou HH, Huang SF, Bai LY, Chang IC, Shiah HS, Ho CL, Yen CJ, Lee KD, Chiu CF, Rau KM, Yu MS, Yang Y, Hsieh RK, Chang JY, Shan YS, Chao Y, Chen LT and Taiwan Cooperative Oncology Group: A KRAS mutation status-stratified randomized phase II trial of gemcitabine and oxaliplatin alone or in combination with cetuximab in advanced biliary tract cancer. Ann Oncol 26(5): 943-949, 2015. PMID: 25632066. DOI: 10.1093/annonc/mdv035

34 Leone F, Marino D, Cereda S, Filippi R, Belli C, Spadi R, Nasti G, Montano M, Amatu A, Aprile G, Cagnazzo C, Fasola G, Siena S, Ciuffreda L, Reni M and Aglietta M: Panitumumab in combination with gemcitabine and oxaliplatin does not prolong survival in wild-type KRAS advanced biliary tract cancer: A randomized phase 2 trial (Vecti-BIL study). Cancer 122(4): 574581, 2016. PMID: 26540314. DOI: 10.1002/cncr.29778

35 Malka D, Cervera P, Foulon S, Trarbach T, de la Fouchardière C, Boucher E, Fartoux L, Faivre S, Blanc JF, Viret F, Assenat E, Seufferlein T, Herrmann T, Grenier J, Hammel P, Dollinger M, André T, Hahn P, Heinemann V, Rousseau V, Ducreux M, Pignon JP, Wendum D, Rosmorduc O, Greten TF and BINGO Investigators: Gemcitabine and oxaliplatin with or without cetuximab in advanced biliary-tract cancer (BINGO): a randomised, open-label, non-comparative phase 2 trial. Lancet Oncol 15(8): 819-828, 2014. PMID: 24852116. DOI: 10.1016/ S1470-2045(14)70212-8

36 Vogel A, Kasper S, Bitzer M, Block A, Sinn M, SchulzeBergkamen H, Moehler M, Pfarr N, Endris V, Goeppert B, Merx K, Schnoy E, Siveke JT, Michl P, Waldschmidt D, Kuhlmann J, Geissler M, Kahl C, Evenkamp R, Schmidt T, Kuhlmann A, Weichert W and Kubicka S: PICCA study: panitumumab in combination with cisplatin/gemcitabine chemotherapy in KRAS wild-type patients with biliary cancer - a randomised biomarkerdriven clinical phase II AIO study. Eur J Cancer 92: 11-19, 2018. PMID: 29413685. DOI: 10.1016/j.ejca.2017.12.028

37 Lee J, Park SH, Chang HM, Kim JS, Choi HJ, Lee MA, Kang JS, Jeung HC, Kang JH, Lee HW, Shin DB, Kang HJ, Sun JM, Park JO, Park YS, Kang WK and Lim HY: Gemcitabine and oxaliplatin with or without erlotinib in advanced biliary-tract cancer: a multicentre, open-label, randomised, phase 3 study. Lancet Oncol 13(2): 181-188, 2012. PMID: 22192731. DOI: 10.1016/S1470-2045(11)70301-1

38 Pietrantonio F, Cremolini C, Petrelli F, Di Bartolomeo M, Loupakis F, Maggi C, Antoniotti C, de Braud F, Falcone A and Iacovelli R: First-line anti-EGFR monoclonal antibodies in panRAS wild-type metastatic colorectal cancer: A systematic review and metaanalysis. Crit Rev Oncol Hematol 96(1): 156-166, 2015. PMID: 26088456. DOI: $10.1016 / j$.critrevonc.2015.05.016 
39 Van Cutsem E, Köhne CH, Hitre E, Zaluski J, Chang Chien CR, Makhson A, D'Haens G, Pintér T, Lim R, Bodoky G, Roh JK, Folprecht G, Ruff P, Stroh C, Tejpar S, Schlichting M, Nippgen $\mathrm{J}$ and Rougier P: Cetuximab and chemotherapy as initial treatment for metastatic colorectal cancer. $\mathrm{N}$ Engl J Med 360(14): 1408-1417, 2009. PMID: 19339720. DOI: 10.1056/ NEJMoa0805019

40 Douillard JY, Siena S, Cassidy J, Tabernero J, Burkes R, Barugel M, Humblet Y, Bodoky G, Cunningham D, Jassem J, Rivera F, Kocákova I, Ruff P, Błasińska-Morawiec M, Šmakal M, Canon JL, Rother M, Oliner KS, Wolf M and Gansert J: Randomized, phase III trial of panitumumab with infusional fluorouracil, leucovorin, and oxaliplatin (FOLFOX4) versus FOLFOX4 alone as first-line treatment in patients with previously untreated metastatic colorectal cancer: the PRIME study. J Clin Oncol 28(31): 4697-4705, 2010. PMID: 20921465. DOI: 10.1200/ JCO.2009.27.4860

41 Vermorken JB, Mesia R, Rivera F, Remenar E, Kawecki A, Rottey S, Erfan J, Zabolotnyy D, Kienzer HR, Cupissol D, Peyrade F, Benasso M, Vynnychenko I, De Raucourt D, Bokemeyer C, Schueler A, Amellal N and Hitt R. Platinumbased chemotherapy plus cetuximab in head and neck cancer. N Engl J Med 359(11): 1116-1127, 2008. PMID: 18784101. DOI: 10.1056/NEJMoa0802656

42 Zhang S, Liang F and Tannock I: Use and misuse of common terminology criteria for adverse events in cancer clinical trials. BMC Cancer 16: 392, 2016. PMID: 27377548. DOI: 10.1186/s12885-016-2408-9

43 Higgins JP, Altman DG, Gøtzsche PC, Jüni P, Moher D, Oxman AD, Savovic J, Schulz KF, Weeks L, Sterne JA, Cochrane Bias Methods Group and Cochrane Statistical Methods Group: The Cochrane Collaboration's tool for assessing risk of bias in randomised trials. BMJ 343: d5928, 2011. PMID: 22008217. DOI: $10.1136 /$ bmj.d5928
44 Cai W, Yuan Y, Ge W, Fan Y, Liu X, Wu D and Hu H: EGFR target therapy combined with gemox for advanced biliary tract cancers: A meta-analysis based on RCTs. J Cancer 9(8): 14761485, 2018. PMID: 29721058. DOI: 10.7150/jca.23290

45 Zhuang X, Xiao YP, Tan LH, Wang LT, Cao Q, Qu GF, Xiao S and Duan HX: Efficacy and safety of chemotherapy with or without targeted therapy in biliary tract cancer: A meta-analysis of 7 randomized controlled trials. J Huazhong Univ Sci Technolog Med Sci 37(2): 172-178, 2017. PMID: 28397047. DOI: $10.1007 / \mathrm{s} 11596-017-1711-2$

46 Petrelli F, Borgonovo K, Cabiddu M, Lonati V and Barni S: Relationship between skin rash and outcome in non-small-cell lung cancer patients treated with anti-EGFR tyrosine kinase inhibitors: a literature-based meta-analysis of 24 trials. Lung Cancer 78: 8-15, 2012. PMID: 22795701. DOI: 10.1016/j.lungcan.2012.06.009

47 Petrelli F, Borgonovo K and Barni S: The predictive role of skin rash with cetuximab and panitumumab in colorectal cancer patients: a systematic review and meta-analysis of published trials. Target Oncol 8: 173-181, 2013. PMID: 23321777. DOI: 10.1007/s11523-013-0257-x

48 Wei F, Shin D and Cai X: Incidence, risk and prognostic role of anti-epidermal growth factor receptor-induced skin rash in biliary cancer: a meta-analysis. Int J Clin Oncol 23(3): 443-451, 2018. PMID: 29289981. DOI: 10.1007/s10147-017-1231-x

Received November 6, 2019

Revised November 12, 2019

Accepted November 18, 2019 